University of San Diego

Digital USD

Undergraduate Honors Theses

Theses and Dissertations

Spring 5-23-2015

\title{
United Nations: Perpetuating Peace? A Historical Overview with a Contemporary Analysis
}

taylor rae noonan

University of San Diego

Follow this and additional works at: https://digital.sandiego.edu/honors_theses

Part of the Other History Commons

\section{Digital USD Citation}

noonan, taylor rae, "United Nations: Perpetuating Peace? A Historical Overview with a Contemporary Analysis" (2015). Undergraduate Honors Theses. 12.

https://digital.sandiego.edu/honors_theses/12

This Undergraduate Honors Thesis is brought to you for free and open access by the Theses and Dissertations at Digital USD. It has been accepted for inclusion in Undergraduate Honors Theses by an authorized administrator of Digital USD. For more information, please contact digital@sandiego.edu. 


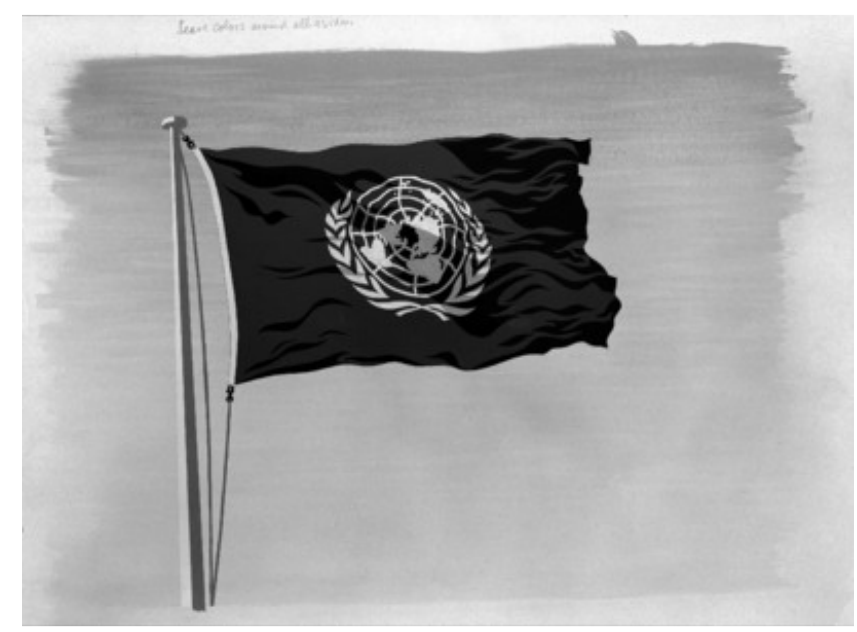

\begin{abstract}
The United Nations is an institution that has been constantly critiqued regarding its efficacy as well as its equitability. In order to analyze this institution in the modern era, it becomes necessary to understand it in light of history, specifically the integral influence of the end of the Cold War. In this paper I will analyze several different aspects of this institution: I will first provide a historical overview of the United Nations and distinguish between the different peace operations. I will answer the questions as to how the end of the Cold War transformed the Peacekeeping Operations, how success is determined in a mission, and what future adaptations should be made so that the United Nations Peacekeeping remains legitimate in the changing times. I will specifically look at the prevalence and possible beneficial shift of power and responsibility of the Security Council as well as the mission mandates and the language used within these mandates.
\end{abstract}




\section{Introduction}

The United Nations, an institution created to promote more peace and security throughout the world by creating a mechanism with which to consolidate all of the nations together to promote common good. Though created for unarguably great causes, this institution often comes under much controversy, and many doubt the ability to instigate successful missions. One way to assess the institution as a whole is by analyzing the Peacekeeping Operations (also called Peacekeeping Missions). When analyzing the Peacekeeping Operations, it becomes apparent that a major shift occurred in the PostCold War era, and that the expanse and scope of the missions have been transformed at this integral point in history. Two major aspects that influence Peacekeeping Operations are the missions' mandates as well as the Security Council that devises them. In this paper I will explain the background of the United Nations, distinguish between the different peace operations, and present the transformation of peacekeeping activity in the Post-Cold-War years. With the historical overview, I will then present the determinants that are necessary to deem a Peacekeeping Operation as a "success". In terms of contemporary analysis, I will focus mainly upon the Security Council and the Peacekeeping mandates. There is consensus that reforms must be had within the United Nations Peacekeeping Missions, and I propose that these changes must occur with a possible shift in the Security Council by becoming more representative of the United Nations as a whole. Also, I propose that the issued mandates be much more succinct and operationalized. It is impossible to measure the success of an institution when the mandates are impossible to ascertain whether or not the objectives have been achieved. This paper overall will assess Peacekeeping Operations from 1948 to the present day, 
noting especially the shift after the Cold War. Success will be defined, and I will propose slight changes in the Security Council and the mission mandates so that the institution of the United Nations can adapt with the changing times.

\section{Historical Overview: What is the United Nations?}

The United Nations is an international organization that is based on perpetuating security, peace, good relationships, progress in society, and human rights in the world. President Franklin Delano Roosevelt first used the term "United Nations" on January 1, 1942, where a declaration for the institution was established. This first declaration involved twenty-six countries that together decided to ban against the Axis Powers during World War II. This was not the first time an international institution had been created to perpetuate this sort of peace and prosperity throughout the world. On the contrary, the front-runner to the United Nations was the League of Nations. The League of Nations came into existence after the disaster of World War I, and thus was a component to the Treaty of Versailles, signed in 1919. However, this institution dissipated after it failed to effectively stop the outbreak of World War II. Still, though, there was a need for this sort of gathering of the nations. Thus, after World War II, on June 26, 1945, representatives from fifty different countries gathered in San Francisco to establish the Charter of the United Nations. In present day, the General Assembly of the United Nations comprises one hundred and ninety three member states. There are several councils of the United Nations, and most authoritative is that of the Security Council. The Security Council includes five permanent members, which include China, France, the Russian Federation, the United Kingdom, as well as the United States. In addition to these five permanent 
members, there also are ten non-permanent members that are cycled in and out every two years. In addition to the Security Council, there is also a fifty-four member Economic and Social Council as well as an International Court of Justice, whose judges are represented by fifteen countries.

In order to understand the United Nations it is important to look at the Charter itself in order to synthesize the goals of the institution and evaluate it in the modern era. First, the United Nations was established to "save the succeeding generations from the scourge of war." After two devastating wars that had completely enveloped and tragically affected most of the world, there was great cooperation to sustain and perpetuate peace. Another key goal, as stated in the Charter, was to reaffirm the value of each individual, and to sustain an environment that promotes justice, perpetuates better living standards on a global scale, and ensure the ability to maintain international law. These far-ranging objectives are distinguished from the early years of Peacekeeping due to their widened scope. However, the countries signed the Charter with the goals of upholding these objectives by doing the following: the countries aimed to uphold tolerance, and promised to be "good neighbors" to the other countries. They aimed to come together in order to strengthen and maintain the ideals of security peace, and armed forces were not to be used unless they were absolutely essential for the betterment of the common interest. They viewed the United Nations as an international mechanism for which all of these objectives could be accomplished. The United Nations was a sort of umbrella that brought the signing nations together for the betterment of mankind and the perpetuation of peace and security. With this peace and security, there are several roles that the United Nations plays. The United Nations has several operations that simultaneously are at work 
in order to fulfill these objectives. (United Nations). There are several aspects to consider even when narrowing the study to peace. Several peace operations are employed on a daily basis, and distinction is necessary between the different operations. After distinguishing between the different operations, the criteria for a successful mission will be discussed.

\section{Peacekeeping Missions: What are they?}

With several different peace operations, it becomes of integral importance to define the different missions in order to measure whether or not that mission is successful. In 2008, the United Nations published a document specifying exactly what the UN Peacekeeping Operations should be encompassing in United Nations Peacekeeping Operations: Principles/Guidelines. The first topic of interest within the document is that of the evolution of operations in peacekeeping. As was stated before, the United Nations was created in order to "save the succeeding generations from the scourge of war". Peacekeeping has been a main mechanism that plays an integral role in achieving this goal. Peacekeeping missions are not specifically mentioned within the UN charter, but the legal basis which provides for these operations include chapters six, seven, and eight of the actual charter. It is highlighted in this document that the human rights should be of the utmost importance in the peacekeeping operations and should be provided within the mandates.

There is a large range of peacekeeping activities, and it becomes of utmost importance to define them specifically. Though the overlap is immense, the clarity of roles in these different aspects of peace helps to ascertain how to best go about a situation that needs peace. First, conflict prevention refers to a situation where the UN becomes involved 
before a conflict breaks out between parties. It encompasses either diplomacy or structural mechanisms in order to quell and mitigate any tension or dispute with the hopes of a compromise or negotiation being reached. Peacemaking is very similar to conflict prevention in that it aims to "bring hostile parties to negotiated agreement" (17) after a conflict arises. Peace Enforcement requires the direct authorization from the Security Council as it uses coercive force, including the military, in order to achieve peace objectives. Peacebuilding typically occurs after a conflict has already been quelled, and it aims to mitigate a relapse of tensions by aiming to bolster the state itself, so that it can sustain itself in "peace and development" (18). Peacekeeping, which will be the focus of this project, has many present roles including military, police and civilians working together to help lay the foundations for sustainable peace" (18). However, peacekeeping has experienced such a large transition as its main role before the end of the Cold War was limited to "observing ceasefires and the separation of forces after inter-state wars" (18). As is evident, there are several aspects to the United Nations effort to perpetuate peace in the modern era. Though there are several distinctions, all of these operations should be "mutually reinforcing" (20). So, though not explicitly stated in the Charter, the legal basis of these operations leaves room for the UN to them in the present day, such as seen with United Nations Peacekeeping Operations: Principles/Guidelines (2008).

\section{Peacekeeping:}

Like the other peace operations, peacekeeping is not explicitly stated within the UN Charter, though the formal practice of peacekeeping began in 1948 with the United Nations Truce Supervision Organization (UNTSO). This first mission involved the 
assurance that Israel and its Arab neighbors upheld their agreements as established in a previous treaty. The second mission was the First United Nations Emergency (19561967), which had the following two objectives: first, France, Israel, and the United Kingdom had recently agreed to give Egypt sovereignty by withdrawing their presence within the land. The United Nations was thus used as a mechanism through which it could ensure that the end of these hostilities would be upheld and that their treaty would be carried out. Second, the UN's role was to serve as a buffer between the Israeli and Egypt forces and to makes sure that the ceasefire was being followed. As exemplified by these first two missions, it becomes evident that in the initial stages of peacekeeping missions, these operations were "limited to ceasefires and stabilizing situations on the ground" (20) via the roles of observation, supervision, and interposition. Before the end of the Cold War, peacekeeping was guided by three main principles, which included the following: consent of the parties involved, impartiality, as well as the non-use of force except in defense of the mandate. However, the end of the Cold War would change the peacekeeping mission roles forever, making success increasingly hard to measure.

\section{Defining a Successful Mission}

Often Peacekeeping Missions are perceived as unsuccessful and expensive. Defining whether a mission is successful or not is essential to maintaining the legitimacy of Peacekeeping Missions in general. Some scholars define success as the simple fulfillment of the official mandate as specified by the United Nations (Janzen 2013). Other scholars add other criteria to determine whether or not a mission is successful. In addition to the mandate, a few determinants could be the following: reducing violence and maintaining 
this conflict within the host borders, perpetuating a resolution, fostering a stable and secure environment, and reducing human suffering (Pushkina 2006). Within this set of criteria, an example of a successful mission would be that of the UN Operation in Mozambique (ONUMOZ 1992-1994). It is considered a success because during this mission, the major violence was mitigated, the environment became more secure in the midst of elections, stability increased as refugees were able to return and resettle, and demobilization of combatants was partially successful. Even after the UN left Mozambique upon the completion of the operation, no major violence ensued, and strides were taken to continue the reconstruction and peacebuilding process. So, a successful operation encompasses those main determinants. Unsuccessful missions, according to this scale, include missions such as the UN Angola Verification Mission III (UNAVEM III 1991-1995). While the UN was operating in Angola, human rights abuses were rampant and the peacekeepers were unable to demobilize and disarm combatants.

One critique of this dichotomous relationship between successful and unsuccessful Peacekeeping Operations is that is often more complicated than simply putting the operation into two categories (Janzen 2013). It is possible to have a mission that is considered "Partially Successful". According to the criteria presented by Pushkina, examples of partially successful missions could be United Nations Peacekeeping Force in Cyprus (UNFICYP 1964), United Nations Transitional Authority in Cambodia (UNTAC 1993), or United Nations Operation in the Congo (UNOC 1960-1964). Within these partial successful missions, some of the criteria are met, while other aspects lack from the operation objectives. From Janzen's perspective, the achievement of four determinants 
("limiting violence, reducing human suffering, containing conflict, and promoting conflict resolution") combined with the objectives stated in the official mandates make a successful operation.

Other scholars present further aspects to keep in mind when evaluating whether or not a mission is successful. Diehl would argue that 1) the mandate must be clear 2) the mandate's objectives must be achieved 3) the operation should have a positive impact on the local population. Durch adds to Diehl's perspective and aims to look more holistically at whether or not the operation helped mitigate the underlying causes that prompted the conflict. Ratner views success as the overall impact that the operation has upon the host country-looking specifically at the opportunity costs of implementing the United Nations. Though scholars differ on exactly what comprises success in a UN operation, however general consensus themes emerge regarding the success: there is a myriad of peacekeeping activities, that it is necessary to have reasonable objectives and expectations for the operations, that the different constituencies and actors have differing goals and motivations for each peacekeeping operation, that a need to define "success" for a mission and to create a "baseline" is a major challenge, and finally conceptually and methodologically it is challenging to evaluate peacekeeping operations. Several other scholars point to the larger scope and "the need for qualitative criteria and the contribution of peacekeeping to larger values such as world peace, justice, and reduction of human suffering" (Druckman \&Sterning 1997). Still other scholars focus on the diplomacy between the different states as the main determinant for success for an operation (Dandeker \& Gow 1997). 
With such a plethora of scholarly perspectives concerning the criteria for success within a peacekeeping operation, it becomes increasingly hard for the public to perceive what is really going on in these missions around the world. I argue that a successful peacekeeping mission is one that strictly follows and achieves the objectives set forth by the UN-issued-mandate. I argue that with the end of the Cold War, the increased scope and lack of quantified language operationalized even within the mandates creates a situation that is impossible to determine the success of the operation. Thus, I argue that success is the accomplishment of the goals within the mandate, and that these objectives should be clear and concise. It becomes obvious that the end of the Cold War had an integral impact on UN Peacekeeping Operations.

\section{Before the Transition: The Beginning Years}

From 1948-1978, there were only thirteen peacekeeping missions. From 1978-1988, there were no new missions. However, from May 1988 to October 1993, there were twenty new missions (UN Database). 1992 alone saw a five fold increase in UN Peacekeeping Activity in terms of capacity as the military and police personnel went from 11,000 troops to 52,000 troops (Goulding 1993). Also, in 1992, the Peacekeeping Mission budget surpassed that of the regular United Nations budget (Diehl and Pharaoh Khan 2000). And, not only was there a dramatic increase in the number of missions, but there was also an increase in the scope of what the missions were supposed to accomplish. Peacekeeping became more "multi-dimensional", transitioning into roles that were not initially under the jurisdiction of peacekeeping. Some of these new aspects included the propensity for the UN to go into the actual state in order to stabilize it and 
bolster its ability to foster a secure environment for its citizens. In addition to this, peacekeeping missions also aimed to improve or even facilitate the actual process of politics and government within the country. Though not explicitly stated in the Charter, the present day UN has adopted the following definition for peacekeeping: protection of civilians, aiding disarmament, demobilizing combatants and also reintegrating them as well, support the organization of elections, as well as the overall arching goal of protecting and promoting the rule of law within a country. United Nations Peacekeeping Operations: Principles/Guidelines (2008) contends that achievement of peace is absolutely contingent upon the improvement in the following four areas of peace: the state must working towards the capabilities to ensure order within society and security in the community. Human rights and the rule of law must be restored and strengthened. Legitimacy of the political institutions is essential, as well as the economic and social recovery after a conflict. This includes the reintegration of humans who have been displaced or put in a place of refuge due to the ensuing conflict. This 2008 report also notes several factors that are necessary for success.

First and foremost this report presents the concept of legitimacy. The legitimacy of a mission is obtained with the official mandate and the backing of the UN Security Council. The Council not only has the responsibility of making sure that the mission goes smoothly, but it also must finance the mission. Legitimacy has several components, and one of these is perceived legitimacy, which has more to do with how the military conducts itself as well as the efficacy thereof. "Be aware of emerging local capacities, and be sensitive to the effect that the behavior and conduct of the mission has on local 
population" (UN, 2008 Report, 37). In addition to legitimacy, and adding to it, is the concept of credibility. Credibility is how the particular mission is viewed by the international and local states in its capabilities to achieve the mandate. This is based on how many troops are deployed, whether the resourcing is adequate, and whether there is a unified base for the mission. Legitimacy and credibility play integral roles in peacekeeping missions (UN 2008). I argue that the end of the Cold War transitioned the legitimacy and credibility in an unprecedented way, and peacekeeping operations would never be the same.

\section{End of the Cold War}

The end of the Cold War had an impact for several different reasons. It made such an integral impact upon the United Nations Peacekeeping Missions because of the prevalence of the Security Council. The Soviet Union and the United States, both permanent members of the Security Council, have veto power. With this sort of system, scarcely any peacekeeping activity could occur during the Cold War. This can be proven via the number of vetoes during the Cold War. From 1945-1990, these countries made the following number of vetoes: The United States and the Soviet Union exercised their veto power substantially more than any of the other permanent members of the Security Council. However, after the end of the Cold War, the United States and the Soviet Union did not exercise this as rigorously as before, and the Security Council was finally on a sort of united front from which they could operate. Instead of fighting among themselves, they viewed any sort of security breach or conflict as a threat to the world as a whole. With this perspective, the Peacekeeping missions increased in number and scope. The 
end of the Cold War and the beginning of the sort of modern era of international relations marked an increased emphasis of the UN combatting the conflict in the world.

\section{Current Statistics on Peacekeeping Missions}

As of March 31, 2015, the number of peacekeeping operations since 1948 is a total of sixty-nine, with sixteen operations still in existence. Uniformed personnel included 91,962 Troops, 13,122 Police, and 1,781 Military Observers. Civilian Personnel included 17,092 total, and 1,846 Volunteers. Personnel of the United Nations is provided for and volunteered by the member states. Individual states pay their own citizens based on individualized salary scales or national rank, and these member states are reimbursed for their troops at a United Nations standard rate. Currently, as approved by all member states, the states are reimbursed $\$ 1,028$ per month per soldier. Currently, the Peacekeeping Operations are far-reaching into Western Sahara, Central Africa Republic, Mali, Haiti, Democratic Republic of Congo, Darfur, Syria, Cyprus, Lebanon, AbyeiSudan, South Sudan, Cote d'Ivoire Kosovo, Liberia, Pakistan, Middle East region. (United Nations).

\section{End of the Cold War Implications}

Several factors are necessary to have a United Nations operation end in success, especially with the changes that have come about after the Cold War. In "The Making of a Security Community: The UN after the Cold War"(1993), Fromuth communicates that the end of the bipolar world was the trading of "the angst of doomsday for the complexity of community living" (341). He argues that these shifts after the end of the Cold War 
made the world a safer place, both in reality and in perception of the citizens. However, with this newfound neighborly contentment and goals for peace and security, he presents several aspects that make community security challenging: the diverse geography and the myriad of cultures within the international community poses a challenge for agreement in the international community as to what security should be pursued. Also, with the end of the imminent nuclear threats, there is fear that negotiations will be made within the states instead of agreement among the different states within the international community. And, one of the final difficulties is that in order to have a successful international community of security, it must involve the whole community, not just the different alliances of Cold War or the victors of World War II (as seen in the Security Council.) Fromuth argues that success depends on the perpetuation of the international community, as legitimized by a normative and legal order (343). He argues that the Security Council is finally fulfilling the role that the original Charter of the UN had intended, as in recent years it has not only increased the momentum and credibility of the Council, but it also has perpetuated the emphasis on an international community. This can be seen in the 1991 intervention concerning Iraq. Due to Iraq's misbehavior concerning weapons of mass destruction as well as the mistreatment and persecution of the Kurdish people within the country, the Security Council began by adopting Resolution 688. This Resolution 688 demanded not only the cooperation of Iraq, but also that the repression of the Kurdish people be stopped and those victims help. It also stipulated that the Secretary-General of the UN could facilitate humanitarian activities. The threat to the entire international community as a whole caused Iraq to have restricted sovereignty through the UN intervention. Though this seemed promising, Resolution 688 is bereft of compulsory power, and thus it was not 
successful until the introduction of force in order to protect the Kurdish community.

Regardless, this action to threaten a nation's sovereignty due to international misbehavior is integral to the transformation and efficacy of the Security Council, as well as the United Nations as a whole.

\section{Prevalence of Security Council}

One integral member of the Security Council is the United States, and through the years, the United States has truly been a top contributor to this institution. However, in 1995, President Bill Clinton of the United States delivered the "Extra Burden" speech via the Presidential Decision Directive (PDD) on the varying peace operations. He created several stipulations as to when the United States should become directly involved with peacekeeping operations. He emphasized that peacekeeping should be a scarce resource, and that the United States should be extremely pragmatic and selective when picking which missions to be involved with. He proposed several aspects for the United States to consider, including the following: whether or not the UN operation will advance the United States' interests, whether the mission is combatting something that is integral to the maintenance of international peace and security. Clinton further communicated that there must be clear objectives, the resources to achieve these objectives and whether inaction is an option, and there also must be a realistic end of the operation in mind as well as both of conflicting parties agreeing and consenting to the ceasefire (Yilmaz 2005). Though this is pragmatic and realistic for the United States, it does pose some problems considering the United States' role in the Security Council. Some scholars question that a prominent member on the Security Council of the UN only involve itself 
that will benefit its' own national interest. Though this is a critique of the United States, from a realist perspective, all states are operating out of this self-interest. The only distinguishing factor is that President Bill Clinton voiced this perspective. Regardless of the political paradigm that a person is operating from, it is obvious that the Security Council holds an uneven distribution of power.

Though the Security Council holds this power, not all literature views this uneven power as a negative aspect of the United Nations. Quite to the contrary, David Bosco argues that the structure of the present day Security Council actually has contributed to more peace in the modern era as it "deepens diplomatic linkages between permanent members". He also notes the increased activity of the Security Council in the last twenty years in the areas of the number of meetings, the peacekeeping missions, the arms embargoes, as well as the sanctions regimes. Bosco sides with the argument Winston Churchill kept, "The only hope for the world is the agreement of the Great Powers". This increasing of relationship can be seen in the fact that since the end of the Cold War, the permanent members of the Security Council have met over two hundred times, thereby increasing the diplomatic relations held. Bosco's argument is that if there is an internal shift within the Security Council, this transformation may have a negative impact on the concert function. He uses historical examples as to how the concert works. A concert, such as in that of Napoleonic Europe, had several aspects. The following are considered: the concert must be limited to the major powers, have the goal of preservation while operating out of a consensus with veto power, and political negotiation is preferred over 
legal obligation. Bosco argues that without this concert, the Security Council would not be performing its key objectives of security and order as well as it could. (Bosco 2014).

However, many would disagree with Bosco when looking at the power disparity within the United Nations Peacekeeping Operations. When looking at the equity of the Security Council, one might think that it would be fairer if each state within the United Nations were given a spot on the Security Council as well as one vote per country. However, this was not the intent of the Security Council-it was never meant to replicate the General Assembly (O'neil, 1996). As is evident, there are a plethora of perspectives regarding the role of the Security Council-as to what would perpetuate its legitimacy and credibility. In addition to legitimacy and credibility for the institution, what shifts in the Security Council should be made to make the Peacekeeping Operations more successful, as specified by the issued mandates.

\section{What are some reforms that could be made within the Security Council?}

"Every legal system undergoes constant change, for law must steadily adjust itself to new realities" (Cassesse 1986). The Norwegian Institute of International Affairs published a paper with a compilation of experts within the field of United Nations Peacekeeping, and accordingly the Security Council's relevance was assessed by political minds (Schia, 2013). It argued, "legitimacy of UN peacekeeping/peacebuilding operations rests on the legitimacy of the Council's decisions" (Peters 10). This is due to the fact that the Security Council Permanent 5 holds veto power, and it thus has the ability to block or sustain missions as it pleases, and often there is not a lot of 
transparency in this process. By having the process hidden, it decreases the legitimacy of the mission, and it negatively impacts UN Peacekeeping as a whole. Possible reforms that these men propose are the following: first, the Security Council should make an effort to make their operations more democratic in nature by increasing the transparency. Secondly, the ten non-permanent members that are cycled in every two years should be given more influence and a more evident "pen-power", more say in the official actions and operations that the UN takes. He also proposes that the Council should pursue increased relations with other regional organizations and member states, especially when the peacekeeping mandates specify these different states. If these few changes were made, the Security Council would be increase its legitimacy, and with this newfound trust in the institution, it is probable that the efficacy of peacekeeping will improve. (Schia). Reform of the United Nations Security Council has been on the General Assembly Agenda since 1979, and several other aspects have been proposed as to how to create a more productive and Security Council conducive to help the institution as a whole. In addition to these reforms, a large emphasis has been on that of transforming the Security Council into one that truly represents the geopolitical interests of the international world at present. It really comes down to a balance of representation, legitimacy, and efficiency (Lee 2011). Increasing any one of these aspects to the Security Council could cause the other core values to decrease. For example, making the Council to be more representative would accomplish that goal, but it might negatively impact the legitimacy of the mission/council.

The prevalence of the Security Council directly impacts the Peacekeeping Operations and the success or failure that these operations achieve. With the five permanent 
members having concentrated power in the form of their veto power, the Peacekeeping Operations may not be as transparent as they could be. Increased transparency in these operations would increase the credibility in the operations, as well as the Security Council as a whole. An integral aspect to consider when thinking about the power discrepancy and stratification of responsibility, it is important to look at what states are responsible for the majority of the funds within the United Nations.

\section{The Funding of Peacekeeping Missions}

Peacekeeping would cease to exist if it was not for the funding, and it is completely dependent upon the member states' cooperation for its continuation. Article XVI of the UN Charter explicitly states that every member country must pay at least some sum, but this allotment is dependent upon a complex formula that has been accepted by the member states. This equation is based on several aspects, including the relative economic wealth of each member state. Due to the power and responsibility enveloped in the role of being a Permanent 5 member, these countries must pay more. Resolution 55/235 passed in 2001, and the financing equation was extrapolated into levels of contribution assignments for each country. For example, "Level A", which included China, France, Russian Fed, UK of Great Britain and North Ireland, and the USA (all members of the Permanent 5) were expected to provide the greatest contribution. However, the lowest tier, "Level J" included countries such as Uganda, Zambia, and Liberia. Though all member-states are required to pay a sum, as of March 2015, there was a debt of 2.17 billion dollars in either previous or current peacekeeping dues (UN website). 
2013-2015 Top Ten Peacekeeping Operations Providers (United Nations) ${ }^{1}$

\begin{tabular}{|c||c|}
\hline Member State & Percent of Overall Contribution \\
\hline United States of America & $28.8 \%$ \\
Japan & $10.83 \%$ \\
France & $7.22 \%$ \\
Germany & $7.14 \%$ \\
United Kingdom & $6.68 \%$ \\
China & $6.64 \%$ \\
Italy & $4.45 \%$ \\
Russian Federation & $3.15 \%$ \\
Canada & $2.98 \%$ \\
Spain & $2.97 \%$ \\
\hline
\end{tabular}

As the world is perpetually in flux, the "New World Order" calls for more money being allocated to perpetuate the peace and security within the world. In the first thirteen peacekeeping missions, the low number of missions along with the succinct goals and objectives of the mandates did not strain the United Nations funds like the financial crisis that is present today. But, at the end of the Cold War, as has been stated many times, the amount of peacekeeping activity increased, and these "second generation" missions proved to be more costly as the scope of roles expanded from the traditional objectives of peacekeeping. In addition, more soldiers, equipment, supplies were needed as well. The approved budget of UN Peacekeeping for July 2014-June 2015 is 8.47 billion dollars. With this large budget, the present debt, and the current widespread missions, the United Nations is amidst a financial crisis. Though there is much debate as to what reforms exactly should be made to address these issues, there are two established consensus

${ }^{1}$ Figure 1: Data taken from the United Nations website 
points: first, the financial crisis is disastrous for the institution and the countries involved, and that nations within the institution want a resolution.

Not only is there a need for reform to keep the institution afloat, but also there are other reasons as to why change is of utmost importance. Because finances are highly debated within the United Nations Peacekeeping missions, the debating and negotiating of the finances costs time. This lost time often translates into bloodshed, such as the United Nations Mission to Namibia in 1989. Some others blame the financial situation as to why the member states of the United Nations were unwilling to allocate more funds or devise a new plan when the missions were failing in Somalia and Rwanda. "Genocide might have been avoided with decisive UN action" (Diehl and Pharaoh Khan 2000, 73). Also, countries that are less developed but members of the United Nations argue that due to the money being allocated to peacekeeping missions, it negatively impacts the ability of funding that would spark economic development. It is of integral importance to make strides to reform the finances of the United Nations.

Current peacekeeping funding is a sort of $a d$ hoc system in that there is not a set plan on peacekeeping funds for the missions due to the inability to plan for the world events that unfold each day. Thus, the planning of financial aspects of missions is done as the missions are presented, and are included in the mandates. Though it is rather spontaneous, the process of peacekeeping funding is not random or special to each individual mission. Rather, patterns are followed, such as following the stipulations set by the UN regular budget or even following funding examples set by other UN missions, 
such as the United Nations Truce Supervision Organization (UNTSO). Though there are guidelines, often the missions at present are more complicated; involving many different factors, or are just in general more expensive than the previous patterns and systems. As with the regular budget, the different member states are required to pay a certain due to the United Nations peacekeeping mission based on an "assessment formula", but this poses a problem when sometimes the member states decide to withhold their dues because of the mission not fitting within their own national interest.

Several solutions have been proposed as to how to redeem the financial situation of the United Nations. First, some simply propose that less peacekeeping missions are pursued, and the ones that are should be short and succinct. "Such proposals do not necessarily mean an increase or decrease in actual amount spent on peacekeeping, but a good proposal is one that can be flexible enough to meet a variety of future scenarios with respect to an increase in the number of missions" (Diehl and Pharaoh Khan 2000,74). There are several proposals, but some deem the most effective is that of an international tax that would collect revenue from the different member states and allocate this money to Peacekeeping Operations. However, this international tax may not meet with approval from the member states as they do not necessarily want to give this institution that kind of power. It becomes obvious that the financial situation needs a standard system, but it is incredibly hard to create reform of this area, because any majors as to the standard may also require a change in the actual UN charter. In order to change the actual charter, an amendment must be approved by two-thirds of all of the United Nations member states and it also must have unanimous support from the permanent five members in the Security Council. If any one of these five vetoes the amendment, the 
whole amendment will be abolished. So, it is extremely hard to achieve reform in this area, and thus the "UN can only do what its' members allow and this applies particularly to financing and its peacekeeping operations" (97). Thus, financing of the peacekeeping activities will likely continue its shortcomings, as reform is extremely hard to be had. Financing, and all reform in general, is hard to come by, and without the support of the states, especially the Permanent 5, little change or no change is likely to occur.

\section{Other Changes Since the Cold War}

When looking to measure the success of the United Nations Peacekeeping Operations, it is important to note that the world is in a perpetual state of flux, and different problems arise. For example, the increase in "organized crime" in the international community. In the twenty-eight peacekeeping missions pursued in 2013 , ten of them included "organized crime" to combat within the mandates. However, "organized crime" is a varied and fluid term, and thus it is hard to truly tackle the objective when the definition is so wide ranging. Francesco Strazzari argues that it is extremely hard to fight "unless the issue features in the public debate, engaging civil society segments, especially sensitive to matters like corruption, development, human rights and social justice" (Willmott and Sheeren 2013, 13).

Another changing issue within peacekeeping is that of increased and new technology. New technology could increase UN Peacekeeping's efficiency and ability to enforce its mandates. However, though there is this advantage, peacekeeping's adversaries also have this new technology. Drones for example pose a threat in that with this new information, 
there also becomes a need for analysis capacity within the UN. John Karlsrud encourages technical companies such as Microsoft and Google to integrate their efforts with those of the UN. With this connection of the private sector and the UN, much productivity could be had. However with this new technology, security must be spread into cyberspace. "Cyberspace is a cornerstone of all societies today" (Willmott and Sheeren 2013, 16) in that the world is connected via these different digital networks. These different networks are integral for states today, as it increases the line of communication between states, increases its economic viability, and it also creates an environment in which society can be more stable. Ignoring these digital networks could have disastrous effects on the process of perpetuating peace.

One further aspect of grievance within the United Nations is the impact and "footprint" that it leaves regarding the civilian population. The Peacekeeping Missions have undoubtedly created much turmoil in the different populations that it has intervened in, regardless of goodwill or helpful intent. Thus, the concept of Protection of Civilians has become of integral importance in the peacekeeping mandates. However, as with all of the recent mandates, there has been an increasing lack of conceptual clarity. This, along with the other mandates, is because the Security Council simply does not want to operationalize its goals, as it holds the member states accountable and uses the resources of the UN. In "The Protection of Civilians Mandate in UN Peacekeeping Operations," Haidi Willmott and Scott Sheeran argue that that "it is necessary to untangle this conceptual and normative confusion" (517) that is so prevalent within the mandates regarding civilians. They both conclude that civilian protection should be specified to 
protecting the civilians from "physical protection from imminent violence" (519). The first UN peacekeeping mission mandate to including the protection of civilians was in 1999, but now it is prevalent in most missions. Regardless of whether it has been specified within the mandate, the protection of civilians has been a goal since the UN Operation in the Congo (UNOC 1960), as this operational directive communicated the following: "Where feasible, every protection will be afforded to unarmed groups who may be subjected by any armed party to acts of violence likely to lead to loss of life." Thus, it becomes necessary for the UN troops to "interpose themselves, using armed force if necessary, to prevent such loss of life". However, this sort of language within the mandates became a sort of anomaly as it almost gave an excuse for armed forces, and it also increased the financial and political stress of the mention. Thus, within the mandate it did not appear again until 1999.

Though this is so, humanitarian aid was given even when it was not specified by the mandate. An example of this is the UN Protection Force in 1992 in former Yugoslavia. In this mission, humanitarian aid was given, and safe areas for civilians were created. However, the good that the UN does is often overshadowed by the tremendous failures. An example of this would be the horrific instances of Bosnia and Rwanda, in which the United Nations turned a blind eye, and some even say that the mission perpetuated, crimes against humanity. After the failure in Democratic Republic of Congo in 2007, again there was a focus on the Responsibility to Protect. For example, in the Libya mission 2011, the mandate specified to "take all necessary measures to protect civilians and civilian populated areas under threat of attack. (Willmott and Sheeren 2013). These 
different arising issues and aspects to consider in Peacekeeping are important to consider because as these issues become a part of the mandates, they also become integral in measuring the operations' success.

\section{Mandates:}

Since the end of the Cold War there has been an increasing trend in mandates towards more normative objectives. As has been emphasized, the original peacekeeping mission mandates were isolated to simply ensuring that already agreed upon mandates were being followed amidst the parties involved. The capacity of mandates increased dramatically at the end of the Cold War. The capacity thereof has been in a myriad of different areas. This increase in scope includes the following: "protect civilians, assist in the disarmament, demobilization and reintegration of former combatants; support the organization of elections, protect and promote human rights assist in restoring the rule of law" (UN).

This increased scope can be seen clearly through the mandates. By carefully noting the language used, it is obvious that there was a shift after the end of the Cold War. As seen in the following figure of a few examples, major themes emerged when looking at the specific verbs used in the mandates. Before the end of the Cold War (all of the peacekeeping missions before 1991), the supervision of the compromise was the main objective being upheld. The mandates were specific and succinct; however, after the end of the Cold War, this was not the case. In addition to the previous basic language used in the first Peacekeeping Missions, the Post-Cold-War mandates included many more roles, and it becomes evident that these mandates were not always a result of a previously- 
agreed-upon treaties, as some entail "facilitating the implementation of agreement" as seen in the UNCRO 1994 in Croatia. So, instead of mainly "observing" and "supervising", the Post-Cold-War Peacekeeping Missions increasing scope can be seen specifically through the language and verbs used.

\section{Examples of Language/Verbs Used through Peacekeeping Mandates.}

\begin{tabular}{l|l|}
\hline \multicolumn{1}{|c|}{ Before the end of the Cold War } & After the end of the Cold War \\
& \\
Secure/Supervise cessation of hostilities & Monitor Cessation of armed forces \\
Withdrawal of armed forces & Monitor/Support the full implementation \\
Serve as a buffer & Facilitating implementation of agreement \\
Certify implementation of agreement & Train Law Enforcement \\
Prevent Recurrent Fighting & Assess threats \\
Prohibit Illegal Infiltration & Promote Confidence among parties \\
Conduct Regular Patrols & Improve safety/security \\
Verify, Confirm, Supervise Ceasefire & Reduce Tensions \\
Monitor Compliance & Monitor/Verify/Observe patrol \\
Investigate alleged Violations & Ensure demilitarization \\
Obtain Agreement with Parties & Support delivery of humanitarian relief \\
Assist parties to resolve local tensions & Supervise/facilitate demilitarization \\
Observe/Report Breeches in ceasefire & Organize elections \\
Ensure Withdrawal & Welcoming inauguration \\
Assist government in law order & Assist to maintain ceasefire \\
Monitor demilitarized zone & Provide interim law enforcement \\
Supervise the Implementation of Resolution & Promotion of national reconciliation ${ }^{2}$
\end{tabular}

For success to be measured by looking to see if the objectives in the mandates have been fulfilled, it is important that the language within the mandate can be operationalized and objectively assessed. It is interesting to note how language plays such an integral role in perception, and how framing dialogue, or in this case, mandates, can influence its efficacy. George Lakoff has written much on the effects that language has, and he

\footnotetext{
2 Figure 2: Language taken from Peacekeeping Mandates via the United Nations Official Site
} 
specifically focuses upon the complex metaphors and framing that occurs in politics. He points to several, including the "heroic-rescue scenario" as well as the "state-as-person" metaphor in which any alternative options are viewed as sub-part to what should be done. An example of this would be "We have to get Saddam out of Kuwait", as said by George H. W. Bush, which justified invasion of Iraq. This is an example of the "state-as-person" metaphor, in which Saddam is representative of the country as a whole, and does not bring into consideration the impact that an invasion will have on other people in the country. Another example is when General Schwarzkopf referred to Iraq's Kuwait occupation as an "ongoing rape". A "heroic-rescue" scenario does not leave an option for another alternative explanation. Instead, it bolsters morale against Iraq as a whole, and demands action to quell the destruction and injustice. Regardless of the veracity of these claims, the language used influences the actions taken after. This, in turn "invites us to infer that nations naturally seek self-interest and may legitimately use military force in the service of their self interest" (Labuschagre and Heidema, 2011). This concept can be applied to the mandates for UN Peacekeeping. Before the end of the Cold War, on of the key values was that of impartiality. Thus, the UN was simply a third-party observe, supervising treaties that had already been signed. However, after the Cold War, it becomes evident that the UN increased its own scope so much that it is relatively impossible to be completely impartial. Some peacekeeping missions' role even include encompassing an interim government or puts the United Nations directly in control of creating a negotiation, instead of merely supporting and upholding the treaty. With the language used in the mandates, the efficacy of the different roles becomes increasingly arbitrary. No one will want to argue with "aiding in humanitarian assistance", though this 
objective may be lacking operationalization or even be a jaded goal in the first place. The use of language cannot be emphasized enough. The need for clear, concise language with operationalized goals also becomes evident.

Further shifts in language can be seen in the area of mandates regarding civilians. The "lack of strategic coherence has, at times, negatively impacted the practical implementation of protection mandates" is apparent in the Modern Era. (Willmot and Sheeran 518). This, along with the civilian failures in the 1990s, as well as the CNN effect, has truly been an integral aspect in calling for a change and clarity in the area of peacekeeping mandates in regards to the civilian rights/population. The CNN effect has been particularly effective in that with the presence of media, citizens have become more cognizant in regards to human suffering due to the pictures and streaming of powerful pictures depicting human suffering.

The first mention of civilian protection in a mandate was that of the UN Operation in the Congo in 1960. The mandate specifically said the following:

“Where feasible, every protection will be afforded to unarmed groups who may be subjected to any armed party to acts of violence likely to lead to loss of life. In such cases, UN troops will interpose themselves, using armed force if necessary, to prevent such loss of life” (UNOC 1960). ?

This type of mandate explicitly stating the protection of civilians became an also the warish nature and lack of impartiality in pursuing such a mandate. However, the 
"Responsibility to Protect" conversation was happening throughout the world, and the protection of citizens become of utmost importance. Even if it was not explicitly stated in the mandate, this humanitarian relief was sought, such as in the UN Protection Force of 1992 in former Yugoslavia. However, the concept of "protection" becomes extremely hard to operationalize, as the term itself is rather arbitrary. "In the absence of operational guidance for implementation, the mandate became open to widely varying interpretations" (521). The failures of citizen protection in the cases of Bosnia and Rwanda further prompted the world to put this particular issue on the platform to be addressed. Sheeran and Willmot propose that in the arena of protection of civilians, there needs to be a "reconciling" of the definitions in the overall mandates, and that these need to specifically focus on protection from "imminent violence" (519). Language is a key component regarding the success of these mandates, and thus the success of Peacekeeping Operations as a whole.

\section{Conclusion: What to do now?}

UN Peacekeeping must adapt with the changing times, and there are several new developments in the modern era that call for this advancement. First, peacekeeping is no longer a local or contained endeavor. Rather, these past decades of have been witness to a development of insurgencies that are inevitably global and local simultaneously (Boas, 2013). The different terrorist groups, such as al-Qaeda in the Islamic Maghreb may have a local context, but the network groups are widespread throughout the world. This becomes hard to resolve with peacekeeping, within context of peacekeeping was undeniably created to be state-focused. However, if peacekeeping is to adapt with the 
changing times, it is of utmost importance to realize the international communities and networks that are at play within the global system.

As Mateja Peter put it in "UN Peace Operations at a Crossroads" (2015), the United Nations has truly been under much scrutiny in recent years regarding the efficacy of its operations. In fact, in October 2014, the UN Security General created a "High Level Independent Panel" in order to specifically focus on assessing UN peacekeeping missions and other special missions. This panel consists of seventeen people, and a joint report is scheduled to come out in June 2015. Consensus can be found in the need for change-an adapting of this institution and its' operations to fit the modern, changing times.

For the purposes of this paper, though, it is evident that the crux of the United Nations' Peacekeeping success lies within the tenants of the individual mandates and the prevalence of the Security Council. The end of the Cold War was an integral turning point in peacekeeping operations, as the scope and number of missions increased dramatically. Along with many scholars, I have defined success in a Peacekeeping Mission as the accomplishment of the objectives listed in the mandate. If the mandates were more operationalized, succinct, and limited, the success of the institution would improve. Also, in terms of the Security Council, if there was some adaptation for which to give more power to other representative states by way of increased responsibility, there would not only be more equality within the institution, from a realist standpoint, it would also provide a legitimacy that is lacking now. Thus, if the Security Council gives a little more power to the non-permanent members, without sacrificing the legitimacy of the 
Permanent 5, the institution as a whole would be more representational while still maintaining the power and responsibility. Huge strides of change will not be taken in the Security Council, because it is not realistic for the Permanent 5 to revoke their veto power or any such power shift, but by possibly increasing the transparency of Peacekeeping and involving more countries in the process, the perception of legitimacy would increase. With this legitimacy, support for the peacekeeping missions may be increased. With a shift in the Security Council, and more clarity in the mandates, the United Nations Peacekeeping Operations would create an environment for success to be measured. 
Works Cited:

Bøås, Morten and Liv Elin Torheim (2013) 'The trouble in Mali - corruption, collusion, resistance', Third World Quarterly 34 (7): 1279-1292.

Bosco, David. (2014). Assessing the UN Security Council: A Concert Perspective. Global Governance 20: 545-561.

Dandeker, C., \& Gow, J. (1997). The Future of Peace Support Operations: Strategic Peacekeeping and Success. Armed Forces \& Society (0095327X), 23(3), 327-347.

Diehi, P. F., , E. (2000). FINANCING UN PEACEKEEPING: A REVIEW AND ASSESSMENT OF PROPOSALS. Policy Studies Review, 17(1), 71-104.

Druckman, Daniel \& Paul Sterning. (1997). Evaluating Peacekeeping Missions. Mershon International Studies Review, 41(1), 152.

Fromuth, P. J. (1993). The making of a security community: The United Nations after the Cold War. Journal Of International Affairs, 46(2), 341.

Goulding, Marrack. The Evolution of United Nations Peacekeeping. International Affairs (Royal Institute of International Affairs 1944-). 69(3): 451-464.

Janzen, R. (2013). DETERMINANTS OF SUCCESS IN UN PEACEKEEPING OPERATIONS. International Journal On World Peace, 30(4), 87-89. 
Labuschagne, Willem and Johannes Heidema. (2011). Leibiniz to Lakoff: Language as instrument for peace. Junctures: The Journal for Thematic Dialogue. 14.

Lee, Seryon. (2011). Feasibility of Reforming the UN Security Council: Too Much Talk, Too Little Action. 4 J. E. Asia \& Int'l L. 405

Oneil, Barry. (1996). Power and Satisfaction in the United Nations Security Council. The Journal of Conflict Resolution. 40(2). 219-237

Peter, Mateja. (2015). United Nations Peace Operations: Aligning Principles and Practice: A compendium of research by the Norwegian Institute of International Affaris. Norwegian Institute of International Affairs, 2.

Pushkina, Darya. (2006). A Recipe for Success? Ingredients of a Successful Peacekeeping Mission. International Peacekeeping. 13(2).

Schia, Niels Nagelhus. (2013). Being part of the parade-going native in the United Nations Security Council. Political and Legal Anthropology Review (PoLAR). 36(1): 138-156.

United Nations Peacekeeping Operations: Principles and Guidelines (2008). United Nations. http://www.un.org/en/peacekeeping/operations/principles.shtml 
United Nations Peacekeeping Statistics

Willmot, Haidi and Scott Sheeran. (2013). The protection of civilians mandate in UN peacekeeping operations: reconciling protection concepts and practices. International Review of the Red Cross. 891(892). 517-538.

Yilmaz, Muzaffer Ercan. (2005). UN Peacekeeping in the Post-Cold War Era. International Journal on World Peace. 22(2): 13 